\title{
Chemical Antagonists of Plasminogen Activator Inhibitor-1: Mechanisms of Action and Therapeutic Potential in Vascular Disease
}

Tessa M Simone, Stephen P Higgins, Craig E Higgins, Michelle R Lennartz and Paul J Higgins*

Center for Cell Biology \& Cancer Research, Albany Medical College, Albany, New York 12208, USA

${ }^{*}$ Corresponding author: Dr. Paul J. Higgins, Center for Cell Biology \& Cancer Research, Albany Medical College, 47 New Scotland Avenue, Albany, New York 12208 , USA, Tel: 518-262-5168; Fax: 518-262-5669; E-mail: higginp@mail.amc.edu

Received date: July 07, 2014, Accepted date: September 16, 2014, Published date: September 21, 2014

Copyright: (2014 TM Simone, et al. This is an open-access article distributed under the terms of the Creative Commons Attribution License, which permits unrestricted use, distribution, and reproduction in any medium, provided the original author(s) and source are credited.

\begin{abstract}
Plasminogen activator inhibitor-1 (PAI-1; SERPINE1) is a member of the serine protease inhibitor (SERPIN) superfamily and the predominant physiologic inhibitor of urokinase (UPA) and tissue-type (tPA) plasmingen activators. This system effectively restricts, both spatially and temporally, the conversion of plasminogen to plasmin, thereby regulating physiologic and pathophysiologic stromal remodeling. Dysregulation of this cascade frequently results in anomalies of the tissue repair response. Elevated PAI-1 levels are a causative factor in various forms of vascular disease and tissue fibrotic syndromes. Independent of its role in proteolysis, PAl-1 stimulates cell motility via interacting with low-density lipoprotein receptor-related protein-1 (LRP1) activating several cellular signaling pathways. PAI-1 also regulates the availability of cell-surface integrins by promoting their endocytosis in an LRP-1dependent manner via PAI-1/uPA/uPAR (UPA receptor)/LRPI/integrin complexes. This process fine tunes the special control of pericellular proteolysis and the overall cadence of cell detachment/re-adhesion required for efficient cell migration. These data suggest that PAI-1 modulates cell motility under several contexts, both via by its established anti-proteolytic properties and as a signaling initiator.
\end{abstract}

Keywords: Plasminogen activator inhibitor; PAI-1; SERPINE1; Vascular disease; Tissue Fibrosis; Small molecule inhibitors

\section{Introduction}

Plasminogen activator inhibitor-1 (PAI-1; SERPINE1), a clade E1 member of the serine protease inhibitor (SERPIN) superfamily, is a major inhibitor of urokinase (uPA) and tissue-type (tPA) plasminogen activators. By limiting the conversion of plasminogen to plasmin, PAI-1 attenuates fibrinolysis, promotes extracellular matrix (ECM) accumulation and contributes to both physiologic and pathophysiologic stromal remodeling (Figure 1). Cooperation between the plasmin-generating and matrix metalloproteinase (MMP) systems is normally closely controlled by a balance between individual proteases and their respective inhibitors. Dysregulation of one or more members in this cascade frequently accompanies chronic disorders and anomalies of the repair response. Elevated PAI-1 levels are, in fact, a significant causative factor in the pathophysiology of diabetes, vascular thrombosis, metabolic syndrome, septic coagulopathy, atherosclerosis, restenosis and myocardial infarction, particularly in the context of increased tissue TGF- $\beta 1$ levels [1-4].

This review focuses on the role of PAI-1 in vascular disease and summarizes current evidence that pharmacologic blockade of PAI-1 function with small molecule inhibitors may have clinical utility as an anti-fibrotic modality. Indeed, oral administration of the PAI-1 inhibitor TM5275 effectively attenuates adenoviral-delivered TGF- $\beta 1$ induced pulmonary fibrosis, stimulated myofibroblast apoptosis and suppressed TGF- $\beta 1$-mediated expression of specific pro-fibrotic genes (e.g., fibronectin, PAI-1) [5].

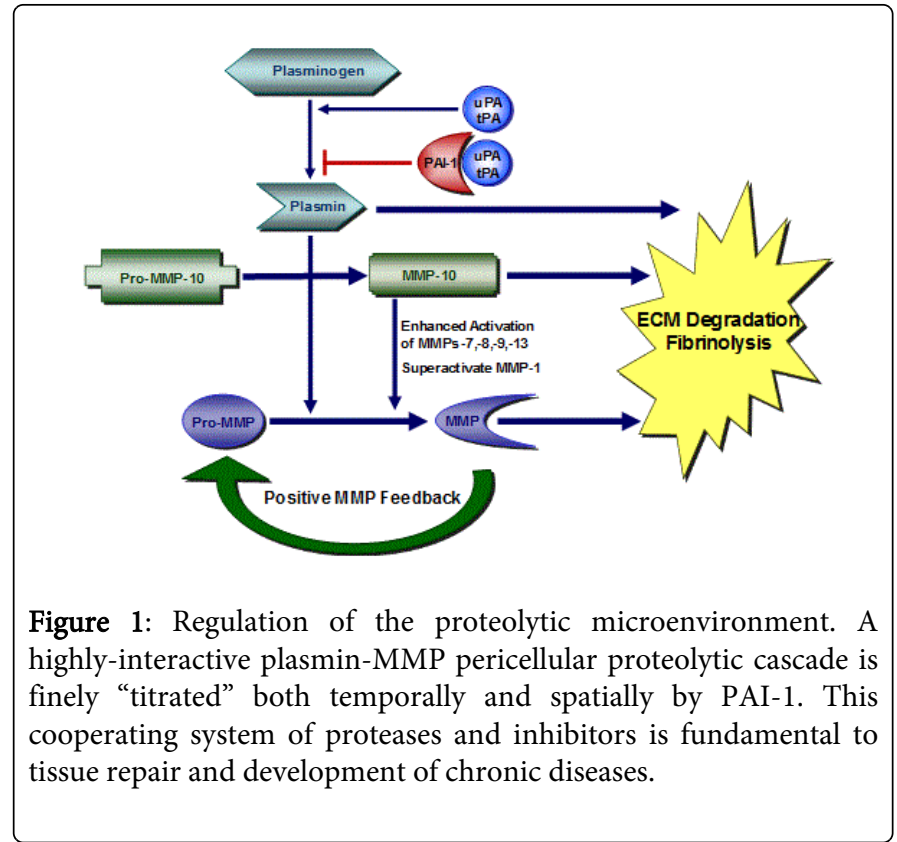

\section{PAI-1 Structure/Function}

PAI- 1 is a single-chain, glycosylated protein, comprised of three $\beta$ sheets $(\mathrm{A}, \mathrm{B}, \mathrm{C})$ and nine $\alpha$-helical domains (A-I) with a strained reactive center loop (RCL) positioned in the carboxy terminus. Inhibition of protease activity occurs by formation of a covalent ester bond between the carboxyl group of Arg346 in the RCL of PAI- 1 and the hydroxyl group of the active site serine in the protease target, mimicking the normal substrate-to-proteinase interaction, followed by 
formation of a reversible Michaelis-like 1:1 stoichiometric complex with its paired proteinase [6,7]. PAI-1 is termed a "suicide inhibitor" as it is rendered inactive by cleavage at the peptide bond (P1-P1') in the RLC upon covalent complexing with the engaged protease $[8,9]$.

PAI-1 is unique relative to other SERPINs as it exists in the structurally and functionally distinct active, latent and cleaved conformations $[10,11]$. PAI-1 is initially synthesized in an active but unstable state (half-life approximately 2 hours at $37^{\circ} \mathrm{C}, \mathrm{pH} 7.4$ ) and converts spontaneously into the latent form. Latency requires insertion of the N-terminus of the PAI-1 RCL into $\beta$-sheet A forming a new $\beta$ strand (s4A) which creates an unusual loop structure and conformational change in the reactive site, disrupting the peptide bond between Arg346 and Met347 (P1-P1') ultimately preventing PAI-1 from interacting with proteinases [12-14]. Alternatively, PAI-1 can be cleaved by target proteases at the peptide bond (P1-P1') without formation of a covalent complex thereby acting as a "substrate". This cleavage causes the $\mathrm{N}$-terminus of the RCL to insert into $\beta$-sheet $\mathrm{A}$, while the C-terminus forms strand s1C in $\beta$-sheet $\mathrm{C}$ producing a $70 \AA$ separation of the $\mathrm{P} 1$ and $\mathrm{P} 1$ ' residues inhibiting $\mathrm{PAI}-1 /$ proteinase intereactions due to spatial distortion [15-17].

\section{PAI-1 in Vascular Pathology}

PAI-1 is abundant in platelets; upon tissue injury, plasma PAI-1 levels increase approximately 10 -fold likely as a consequence of platelet activation [18-20]. PAI-1 rapidly inhibits both tissue-type (tPA) and urokinase (uPA) plasminogen activators with second order rate constants approximating $3.5 \times 10^{7} \mathrm{M}^{-1} \mathrm{~s}^{-1}[14,21,22]$. The primary role of the plasminogen activator system is to generate the active enzyme plasmin from its zymogen precursor, plasminogen, a key step in the fibrinolytic cascade [23-25]. Indeed, PAI-1 deficiency in humans results in a hyperfibrinolytic state and abnormal bleeding after trauma or surgery [26-30]. PAI-1 is a critical, rate-limiting, factor that impacts thrombosis, fibrin accumulation and ECM remodeling [31]. Inhibition of the fibrinolytic system by PAI-1 overexpression, moreover, has been implicated in various pathologies including tissue fibrosis, metabolic disorders and cardiovascular disease (i.e., atherosclerosis, vessel stenosis). A recent report, furthermore, highlights this causative relationship and provides evidence that a small molecule PAI-1 inhibitor (TM5441) confers protection to the development of cardiac hypertrophy, hypertension and periaortic fibrosis in L-NAME-treated mice $[32,33]$.

Atherosclerosis: The first clinical association of increased PAI-1 with cardiovascular pathology was the finding of elevated plasma PAI-1 levels in young survivors of myocardial infarction (MI); PAI-1 levels were a significant risk factor for infarct recurrence [34,35]. PAI-1 increases precede MI and predispose patients to MI independent of other risk factors [36,37]. As infarct is caused by interrupted blood flow as a result of a ruptured vulnerable atherosclerotic plaque, correlations between PAI-1 and atherosclerosis resulted in the discovery of high PAI-1 levels in vascular lesions suggesting that this SERPIN plays an integral role in atherogenesis [38-40]. Importantly, atherosclerosis-prone apolipoprotein E-null (ApoE-/-) mice had a 3-fold up-regulation in plasma and smooth muscle cell PAI-1 mRNA in advanced atherosclerotic lesions compared to wild-type controls [41] suggesting a role in disease progression (e.g., Figure 2). As Proof-of-concept, double deficient PAI-1-/-/ApoE-/- mice had decreased neointima formation after ferric chloride-induced arterial injury compared to PAI-1+/+/ApoE-/controls [42]. There are, however, contrary data. PAI-1 deficiency augmented atherosclerotic progression in the ApoE-/- genetic background in one study $[43,44]$ while a cross of LDL receptor-null, atherosclerosis-prone with PAI-1-/- mice did not change vessel lesion formation [44]. Complicating this issue, while atherosclerosis in the aorta of PAI-1-/-/ApoE-/- and PAI-1+/+/ApoE-/- were similar, there was a decrease in disease progression at the carotid bifurcation in PAI-1-/-/ApoE-/- suggesting PAI-1 may potentiate lesion development at sites of turbulent flow [45]. Since atherogenesis involves lipid accumulation, persistent inflammation, vascular injury, fibrin as well as ECM deposition, elevated PAI-1 expression and its major tissue injury-associated inducer TGF- $\beta 1[3,46]$ it is likely the atherosclerotic response will vary as a function of vascular site, blood flow mechanics, type of injury, tissue levels of PAI- 1 and TGF- $\beta 1$, plaque vulnerability, genetic background and other disease co-factors.
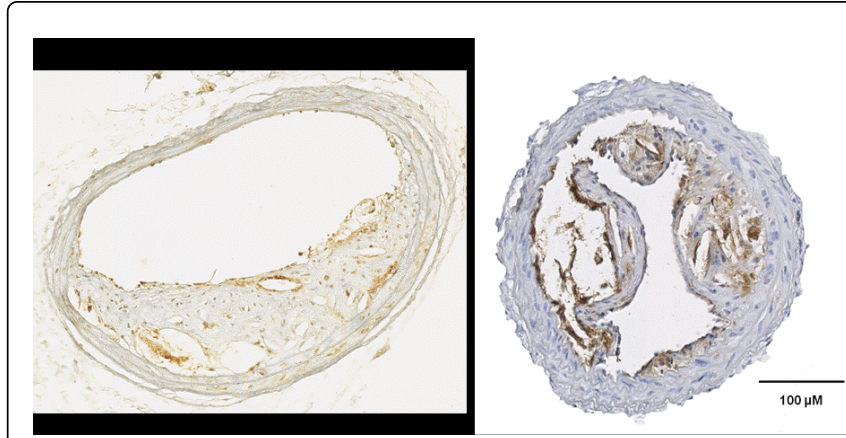

Figure 2: Induction of carotid plaques in mice and PAI-1 immunohistochemistry. In humans, atherosclerosis develops in areas of low shear stress and oscillatory blood flow. Placement of shear stress-modifying cuff or conical cast around the common carotid artery in mice mimics the disturbed blood flow characteristic of human carotid arteries [47,48]. Constriction promotes the formation of vulnerable plaques proximal to the device. In atherosclerosis prone ApoE-/- mice, carotid cuffing induces plaques with foam cells, necrosis, and thin fibrous caps that are hallmarks of vulnerable human plaques; $~ 30 \%$ of ApoE-/plaques have intraplaque red blood cells, indicative of rupture [48]. Section on left exhibits a neointima with abundant PAI-1+ cells (brown deposits); right section illustrates a PAI-1 immunoreactive inflammatory plaque. One advantage of this model is the accessibility of the carotid arteries to ultrasound biomicroscopy, enabling longitudinal studies of plaque formation and providing an evaluation tool for the effects of drug treatment. Ultrasound may eventually be tuned to discriminate between stable and unstable human plaques. The details of the mouse carotid constriction model and blood flow characterization have been published [49]. All animal procedures were approved by the Albany Medical Center Institutional Animal Care and Use Committee (protocol \# 912461) and carried out in compliance with NIH regulations. While both wild-type and genetically-engineered mice have proven invaluable in the implication of PAI-1 in cardiovascular and fibrotic disease, caution is warranted in extrapolating data from the various murine models of vascular injury to human disease since PAI-1 levels, both in plasma and platelets, are significantly lower in mice (discussed in [50]). These data illustrate the relationship between carotid cuff injury and PAI-1 expression as well as highlight the lack of a neointimal response to placement of copper cuffs around the carotid arteries of PAI-1-/- mice [51]. 
Neointimal hyperplasia and stenosis: Currently, the main treatment for atherosclerosis is transluminal coronary angioplasty (with and without stent placement). This procedure often results in pathological remodeling and restenosis, a major limitation to clinical intervention. Treatment, and prevention, of in-stent restenosis have been disappointing. Drug-eluting stents, moreover, pose a significant danger of late thrombosis even after successful implantation [52]. Elevated PAI-1 mRNA/protein expression in the vascular wall adjacent to a thrombus was evident upon implantation of indwelling polyethylene tubing in rabbit carotid arteries [53]. Furthermore, adenoviral delivery of PAI-1 potentiated neointima formation after balloon-catheter angioplasty [54] while neointima formation was markedly attenuated following copper-induced arterial injury in PAI-1-/- mice [55]. Similarly, using a carotid artery ligation model, PAI-1 protein levels were elevated in neointimal lesions 14-days after occlusion (Figure 3, compare bottom left to bottom right). PAI-1 expression, furthermore, co-localized with smooth muscle $a$-actin suggesting synthesis by smooth muscle cells (Figure 3, top left). Importantly, in post-transluminal coronary angioplasty PAI-1 activity was significantly greater in patients with restenosis compared to those without recurrence [56,57].

\section{PAI-1 as a Regulator of Cell Migration: A Key Event in Vessel Stenosis?}

PAI-1 modulates cellular migration in response to tissue or monolayer injury [58] likely as part of the grow-or-go dichotomy [59]. Medial smooth muscle cell migration and proliferation, followed by ECM synthesis, is a central mechanism in the development of vascular restenosis in post-angioplasty patients. TGF- $\beta 1$, a prominent profibrotic vascular factor, increases intimal expansion via smooth muscle cell migration in both injured and uninjured arteries and elevated levels of TGF- $\beta 1$ are evident in human restenotic lesions [60-64]. TGF- $\beta 1$ appears to stimulate neointimal development through upregulation of PAI-1 [3]. PAI-1 positively impacts cellular motility both through its anti-proteolytic and signaling functions. Receptorengaged UPA and PAI-1 focalize to the leading edge of a migrating cell where they titer cell-ECM interactions, thereby regulating spatiotemporal deposition of matrix, providing a platform for cell migration $[65,66]$. Alternatively, PAI-1 can modulate cell locomotion by binding to vitronectin via RGD-dependent interactions which effectively stabilizes PAI-1 activity by extending its half-life while displacing vitronectin from its $\alpha v \beta 3$ and $\alpha v \beta 5$ integrin receptors [67].

Independent of its role in proteolysis, PAI-1 stimulates cell motility via interacting with low-density lipoprotein receptor-related protein-1 (LRP1) triggering Jak/Stat1 signaling [68]. The three conformations of PAI-1 (active, latent and cleaved) bind LRP1, activate the Jak/Stat pathway and drive migration [69,70]. PAI-1 also regulates the availability of cell-surface integrins by promoting their endocytosis in an LRP-1-dependent manner via PAI-1/uPA/uPAR (uPA receptor)/ LRPI/integrin complexes. While PAI-1 and UPA are degraded, UPAR, LRP-1 and integrins are recycled back to the leading edge. This process fine tunes the special control of pericellular proteolysis and the overall cadence of cell detachment/re-adhesion required for efficient cell migration [71-73]. These data suggest that PAI-1 modulates cell motility under several contexts, both via anti-proteolysis and as a signaling molecule, particularly in the setting of increased injuryassociated tissue TGF- $\beta 1$ levels.

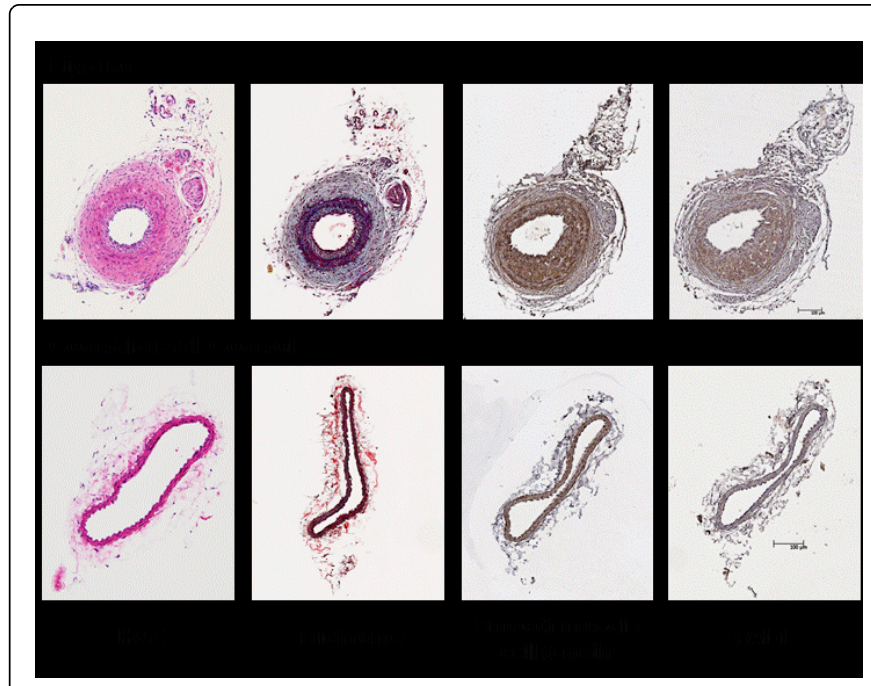

Figure 3: Carotid ligation-induced PAI-1 expression. FVB/NJ mice (Jackson Labs) were anesthetized by intraperitoneal injection of ketamine $(0.1 \mathrm{mg} / \mathrm{gm})$ and xylazine $(0.01 \mathrm{mg} / \mathrm{gm})$. Following incision site preparation, the left carotid artery was exposed with a small $8-10 \mathrm{~mm}$ midline incision in the neck and blunt dissection to free the left common carotid artery and branches from surrounding tissue. The common carotid artery was ligated proximal to the internal and external carotid bifurcation with a 6-0 sterile silk suture. The incision site was closed using 5-0 silk suture in a subcuticular pattern. Paraffin-embedded sections were stained with $\mathrm{H} \& \mathrm{E}$ as well as with Trichrome reagent; immunohistochemistry utilized antibodies to smooth muscle $\beta$-actin and PAI-1 as described [57].

\section{Low Molecular Weight PAI-1 Antagonists}

Several low molecular weight antagonists of PAI-1 are available [74] (Table 1). The first were diketopiperazines (XR330 and XR334) and the later, more potent, antagonists (XR1853, XR5082, XR5967, XR1121) which inhibit PAI-1 by inducing the transition from active PAI-1 to non-reactive PAI-1 [75-77]. Furthermore, by inhibiting the interaction of $\mathrm{tPA} / \mathrm{uPA}$ and PAI- 1 in a rat carotid artery thrombus model, XR334, XR5082 and XR1853 effectively increase fibrinolysis in vivo [76]. Similarly, AR-H029953XX and fendosalanthranalic acid derivatives of the known fibrinolytic antagonist flufenamic acid both inhibit PAI-1 by direct conversion into the latent, nonreactive conformation, but have not been tested in vivo [45-47].

The negatively charged antagonists ANS, bis-ANS and 1-dodecyl sulphurc acid and the positively charged XR-5118 overlap and localize around the flexible joint region of PAI-1, thereby inhibiting the RCL accessibility during interaction with proteinases [78-80]. This conformational rearrangement causes the reactive site to become inaccessible, thereby preventing tPA and uPA from binding and ultimately preventing the antiproteolytic capacity of PAI-1[80]. Of these, only XR-5118 has in vivo efficacy by increasing tPA activity and both reduced rat and rabbit arterial thrombus growth [81,82].

Recently, a class of polyphenolic compounds was found to inhibit PAI-1 with 10-1000-fold improved potency [83]. These compounds were found to reversibly interfere with the initial association of PAI-1 with its target protease, and two of the compounds (CDE-066 and 
Citation: $\quad$ Simone TM, Higgins SP, Higgins CE, Lennartz MR and Higgins PJ (2014) Chemical Antagonists of Plasminogen Activator Inhibitor-1: Mechanisms of Action and Therapeutic Potential in Vascular Disease. J Mol Genet Med 8: 125. doi:10.4172/1747-0862.1000125

Page 4 of 7

CDE-081) showed efficacy in ex vivo plasma [83]. Only CDE-066 has in vivo efficacy, as evidenced by its ability to block PAI-1 activity in mice overexpressing PAI-1 [83]. Similarly, the PAI-1 inhibitor, IMD-1622 significantly reduced thrombi formation following rat arterial injury and inhibited neointimal formation in response to a murine copper-wire injury model [84]. Additionally, Tiplaxtinin and TM5007, indoleoxoacetic acid derivatives molecules which antagonize the activity of PAI- 1 by inserting into the s4A position of $\beta$-sheet $\mathrm{A}$ as a mock molecule thereby inhibiting the PAI-1/tPA complex formation have also been designed $[85,86]$. Importantly, both of these compounds, Tiplaxtinin and TM5007, are metabolically stable, nontoxic and showed good oral bioavailability and in vivo efficacy in a rat thrombosis model $[85,87]$. Tiplaxtinin, the most well studied low molecular weight inhibitor of PAI-1, attenuates asthmatic flare-ups, obesity, diabetes, cancer cell motility and angiogenesis in various studies, and is the only low molecular weight antagonist of PAI-1 discussed here to be studied in a restenotic animal model [88-95]. Inhibition of PAI-1 with tiplaxitin caused significant reduction in Angiotensin II (Ang II)-induced medial, adventitial, and aortic wall thickening through a blood pressure dependent mechanism [95].

\section{Significance and Clinical Implications}

Currently, transluminal coronary angioplasty, a procedure that often results in substantial pathological remodeling, predispose to restenosis with considerable implications in cardiovascular health. Given the information regarding increased PAI-1 expression and activity in the development of neointimal hyperplasia, efforts have focused on pharmacological inhibitors of PAI-1 that may be clinical applicable. Only Tiplaxtinin has been shown to reduce neointimal growth. Recently, we observed that Tiplaxtinin inhibits PAI-1 and TGF- $\beta 1$-induced vascular smooth muscle migration and phosphorylation of Akt (not shown). As our data and others suggests, PAI-1 may modulate pathological remodeling of an injured vessel by promoting cell motility and survival. Further research into these small molecule inhibitors of PAI-1 is necessary to fully define the role PAI-1 in vascular smooth muscle cell biology and to assess the potential utilization in pharmacological intervention of neointimal disease.

\begin{tabular}{|c|c|c|c|}
\hline Mechanism of action & Designation & In vivo & Refs \\
\hline \multirow{7}{*}{$\begin{array}{l}\text { Induces reactive center loop } \\
\text { inaccessibility }\end{array}$} & 1-dodecyl sulfuric acid & Not reported & {$[79,96]$} \\
\hline & ANS & Not reported & {$[77,79,96,97]$} \\
\hline & Bis-ANS & Not reported & {$[79,96,97]$} \\
\hline & IMD-1622 & $\begin{array}{l}\text { Reduced rat arterial thrombus formation, and neointimal } \\
\text { formation }\end{array}$ & [84] \\
\hline & Tiplaxtinin & $\begin{array}{l}\text { Reduced rat arterial thrombus growth, and reduced Ang } \\
\text { Il-induced medial, adventitial, and aortic wall thickening }\end{array}$ & {$[87,95]$} \\
\hline & TM5007 & Reduced rat arterial thrombus & [85] \\
\hline & XR5118 & Reduced rat arterial thrombus & [82] \\
\hline \multirow{8}{*}{ Inactivating } & AR-H029953XX & Not reported & {$[77,79,97]$} \\
\hline & Fendosal & Not reported & [77] \\
\hline & XR11211 & Not reported & [75] \\
\hline & XR1853 & Reduced rat arterial thrombus & {$[76,77]$} \\
\hline & XR330 & Not reported & [78] \\
\hline & XR334 & Reduced rat arterial thrombus & {$[76,78]$} \\
\hline & XR5082 & Reduced rat arterial thrombus & {$[76,77]$} \\
\hline & XR5967 & Not reported & [98] \\
\hline \multirow{2}{*}{$\begin{array}{l}\text { Inhibits initial interaction between PAl-1 } \\
\text { and protease }\end{array}$} & CDE-066 & Reduced PAI-1 activity & [83] \\
\hline & CDE-082 & Not reported & [83] \\
\hline
\end{tabular}

Table 1: Mechanism of action

\section{Acknowledgements}

Supported by NIH grants GM057242 (PJH), HL095971 and HL089730 (MRL), the Graver Family Foundation (PJH) and AHA Fellowship 14PRE18170012 (TMS).

\section{References}

1. iebold I, Kraicun D, Bonello S, Görlach A (2008) The 'PAI-1 paradox' in vascular remodeling. ThrombHaemost 100: 984-991.

2. De Taeye B, Smith LH, Vaughan DE (2005) Plasminogen activator inhibitor-1: a common denominator in obesity, diabetes and cardiovascular disease. Curr Opin Pharmacol 5: 149-154. 
Page 5 of 7

3. Otsuka, G, Agah, R, Frutkin, AD, Wight, TN, and Dichek, DA (2006) Transforming growth factor beta 1 induces neointima formation through plasminogen activator inhibitor-1-dependent pathways. Arterioscler Thromb Vasc Biol 26: 737-43.

4. Ghosh AK, Vaughan DE (2012) PAI-1 in tissue fibrosis. J Cell Physiol 227: 493-507.

5. Huang WT, Vayalil PK, Miyata T, Hagood J, Liu RM (2012) Therapeutic value of small molecule inhibitor to plasminogen activator inhibitor-1 for lung fibrosis. Am J Respir Cell Mol Biol 46: 87-95.

6. Odani S, Koide T, Ono T (1983) The complete amino acid sequence of barley trypsin inhibitor. J BiolChem 258: 7998-8003.

7. Egelund R, Rodenburg KW, Andreasen PA, Rasmussen MS, Guldberg RE, et al. (1998) An ester bond linking a fragment of a serine proteinase to its serpin inhibitor. Biochemistry 37: 6375-6379.

8. Wilczynska M, Fa M, Ohlsson PI, Ny T (1995) The inhibition mechanism of serpins. Evidence that the mobile reactive center loop is cleaved in the native protease-inhibitor complex. J Biol Chem 270: 29652-29655.

9. Lawrence DA, Ginsburg D, Day DE, Berkenpas MB, Verhamme IM, et al. (1995) Serpin-protease complexes are trapped as stable acyl-enzyme intermediates. J Biol Chem 270: 25309-25312.

10. Declerck, PJ, De Mol, M, Vaughan, DE, and Collen, D (1992) Identification of a conformationally distinct form of plasminogen activator inhibitor-1, acting as a noninhibitory substrate for tissue-type plasminogen activator. J Biol Chem 267: 11693-6.

11. Urano, T, Strandberg, L, Johansson, LB, and Ny, T (1992) A substratelike form of plasminogen-activator-inhibitor type 1. Conversions between different forms by sodium dodecyl sulphate. Eur J Biochem 209: 985-92.

12. Mottonen J, Strand A, Symersky J, Sweet RM, Danley DE, et al. (1992) Structural basis of latency in plasminogen activator inhibitor-1. Nature 355: 270-273.

13. Levin EG, Santell L (1987) Conversion of the active to latent plasminogen activator inhibitor from human endothelial cells. Blood 70: 1090-1098.

14. Lindahl TL, Sigurdardottir O, Wiman B (1989) Stability of plasminogen activator inhibitor 1 (PAI-1). Thromb Haemost 62: 748-751.

15. Patston PA, Gettins P, Beechem J, Schapira M (1991) Mechanism of serpin action: evidence that $\mathrm{C} 1$ inhibitor functions as a suicide substrate. Biochemistry 30: 8876-8882.

16. Gils A, Declerck PJ (1997) Proteinase specificity and functional diversity in point mutants of plasminogen activator inhibitor 1. J Biol Chem 272: $12662-12666$.

17. Aertgeerts K, De Bondt HL, De Ranter CJ, Declerck PJ (1995) Mechanisms contributing to the conformational and functional flexibility of plasminogen activator inhibitor-1. Nat Struct Biol 2: 891-897.

18. Juhan-Vague I, Moerman B, De Cock F, Aillaud MF, Collen D (1984) Plasma levels of a specific inhibitor of tissue-type plasminogen activator (and urokinase) in normal and pathological conditions. Thromb Res 33: 523-530.

19. Kruithof, EK, Nicolosa, G, and Bachmann, F (1987) Plasminogen activator inhibitor 1: development of a radioimmunoassay and observations on its plasma concentration during venous occlusion and after platelet aggregation. Blood 70: 1645-53.

20. Erickson LA, Ginsberg MH, Loskutoff DJ (1984) Detection and partial characterization of an inhibitor of plasminogen activator in human platelets. J Clin Invest 74: 1465-1472.

21. Lawrence DA, Olson ST, Palaniappan S, Ginsburg D (1994) Engineering plasminogen activator inhibitor 1 mutants with increased functional stability. Biochemistry 33: 3643-3648.

22. Seiffert, D and Loskutoff, DJ (1991) Kinetic analysis of the interaction between type 1 plasminogen activator inhibitor and vitronectin and evidence that the bovine inhibitor binds to a thrombin-derived aminoterminal fragment of bovine vitronectin. Biochim Biophys Acta 1078: $23-30$.
23. Myöhänen H, Vaheri A (2004) Regulation and interactions in the activation of cell-associated plasminogen. Cell Mol Life Sci 61: 2840-2858.

24. Cesarman-Maus G, Hajjar KA (2005) Molecular mechanisms of fibrinolysis. Br J Haematol 129: 307-321.

25. Fay WP, Garg N, Sunkar M (2007) Vascular functions of the plasminogen activation system. Arterioscler Thromb VascBiol 27: 1231-1237.

26. Schleef RR, Higgins DL, Pillemer E, Levitt LJ (1989) Bleeding diathesis due to decreased functional activity of type 1 plasminogen activator inhibitor. J Clin Invest 83: 1747-1752.

27. Diéval J, Nguyen G, Gross S, Delobel J, Kruithof EK (1991) A lifelong bleeding disorder associated with a deficiency of plasminogen activator inhibitor type 1. Blood 77: 528-532.

28. Lee MH1, Vosburgh E, Anderson K, McDonagh J (1993) Deficiency of plasma plasminogen activator inhibitor 1 results in hyperfibrinolytic bleeding. Blood 81: 2357-2362.

29. Minowa H, Takahashi Y, Tanaka T, Naganuma K, Ida S, et al. (1999) Four cases of bleeding diathesis in children due to congenital plasminogen activator inhibitor-1 deficiency. Haemostasis 29: 286-291.

30. Fay WP, Parker AC, Condrey LR, Shapiro AD (1997) Human plasminogen activator inhibitor-1 (PAI-1) deficiency: characterization of a large kindred with a null mutation in the PAI-1 gene. Blood 90: 204-208.

31. Ploplis VA (2011) Effects of altered plasminogen activator inhibitor-1 expression on cardiovascular disease. Curr Drug Targets 12: 1782-1789.

32. Boe, AE, Eren, M, Murphy, SB, Kamide, CE, Ichimura, A, et al. (2013) Plasminogen activator inhibitor-1 antagonist TM5441 attenuates Nomega-nitro-L-arginine methyl ester-induced hypertension and vascular senescence. Circulation 128: 2318-24.

33. Simon DI, Simon NM (2013) Plasminogen activator inhibitor-1: a novel therapeutic target for hypertension? Circulation 128: 2286-2288.

34. Hamsten A, de Faire U, Walldius G, Dahlén G, Szamosi A, et al. (1987) Plasminogen activator inhibitor in plasma: risk factor for recurrent myocardial infarction. Lancet 2: 3-9.

35. Hamsten A, Wiman B, de Faire U, Blombäck M (1985) Increased plasma levels of a rapid inhibitor of tissue plasminogen activator in young survivors of myocardial infarction. N Engl J Med 313: 1557-1563.

36. Juhan-Vague I, Pyke SD, Alessi MC, Jespersen J, Haverkate F, et al. (1996) Fibrinolytic factors and the risk of myocardial infarction or sudden death in patients with angina pectoris. ECAT Study Group. European Concerted Action on Thrombosis and Disabilities. Circulation 94: 2057-2063.

37. Thogersen AM, Jansson JH, Boman K, Nilsson TK, Weinehall L, et al. (1998) High plasminogen activator inhibitor and tissue plasminogen activator levels in plasma precede a first acute myocardial infarction in both men and women: evidence for the fibrinolytic system as an independent primary risk factor. Circulation 98: 2241-7.

38. Schneiderman J, Sawdey MS, Keeton MR, Bordin GM, Bernstein EF, et al. (1992) Increased type 1 plasminogen activator inhibitor gene expression in atherosclerotic human arteries. Proc Natl Acad Sci U S A 89: 6998-7002.

39. Lupu F, Bergonzelli GE, Heim DA, Cousin E, Genton CY, et al. (1993) Localization and production of plasminogen activator inhibitor-1 in human healthy and atherosclerotic arteries. Arterioscler Thromb 13: 1090-1100.

40. Chomiki N, Henry M, Alessi MC, Anfosso F, Juhan-Vague I (1994) Plasminogen activator inhibitor-1 expression in human liver and healthy or atherosclerotic vessel walls. Thromb Haemost 72: 44-53.

41. Schafer, K, Muller, K, Hecke, A, Mounier, E, Goebel, J, et al. (2003) Enhanced thrombosis in atherosclerosis-prone mice is associated with increased arterial expression of plasminogen activator inhibitor-1. Arterioscler Thromb Vasc Biol 23: 2097-103. 
42. Zhu Y, Farrehi PM, Fay WP (2001) Plasminogen activator inhibitor type 1 enhances neointima formation after oxidative vascular injury in atherosclerosis-prone mice. Circulation 103: 3105-3110.

43. Luttun A, Lupu F, Storkebaum E, Hoylaerts MF, Moons L, et al. (2002) Lack of plasminogen activator inhibitor-1 promotes growth and abnormal matrix remodeling of advanced atherosclerotic plaques in apolipoprotein E-deficient mice. Arterioscler Thromb Vasc Biol 22: 499-505.

44. Sjöland H, Eitzman DT, Gordon D, Westrick R, Nabel EG, et al. (2000) Atherosclerosis progression in LDL receptor-deficient and apolipoprotein E-deficient mice is independent of genetic alterations in plasminogen activator inhibitor-1. Arterioscler Thromb Vasc Biol 20: 846-852.

45. Eitzman, DT, Westrick, RJ, Xu, Z, Tyson, J, and Ginsburg, D (2000) Plasminogen activator inhibitor-1 deficiency protects against atherosclerosis progression in the mouse carotid artery. Blood 96: 4212-5.

46. Otsuka G, Stempien-Otero A, Frutkin AD, Dichek DA (2007) Mechanisms of TGF-beta1-induced intimal growth: plasminogenindependent activities of plasminogen activator inhibitor-1 and heterogeneous origin of intimal cells. Circ Res 100: 1300-1307.

47. von der Thüsen JH, van Vlijmen BJ, Hoeben RC, Kockx MM, Havekes $\mathrm{LM}$, et al. (2002) Induction of atherosclerotic plaque rupture in apolipoprotein E-/- mice after adenovirus-mediated transfer of p53. Circulation 105: 2064-2070.

48. Cheng C, Tempel D, van Haperen R, van der Baan A, Grosveld F, et al. (2006) Atherosclerotic lesion size and vulnerability are determined by patterns of fluid shear stress. Circulation 113: 2744-2753.

49. Harmon EY, Fronhofer V, Keller RS, Feustel PJ, Brosnan MJ, et al. (2012) Ultrasound biomicroscopy for longitudinal studies of carotid plaque development in mice: validation with histological endpoints. PLoS One 7: e29944.

50. Declerck PJ, Gils A (2013) Three decades of research on plasminogen activator inhibitor-1: a multifaceted serpin. Semin Thromb Hemost 39: 356-364.

51. Ploplis VA, Castellino FJ (2001) Attenuation of neointima formation following arterial injury in PAI-1 deficient mice. Ann N Y Acad Sci 936: 466-468.

52. Lüscher TF, Steffel J, Eberli FR, Joner M, Nakazawa G, et al. (2007) Drugeluting stent and coronary thrombosis: biological mechanisms and clinical implications. Circulation 115: 1051-1058.

53. Sawa H, Sobel BE, Fujii S (1993) Potentiation by hypercholesterolemia of the induction of aortic intramural synthesis of plasminogen activator inhibitor type 1 by endothelial injury. Circ Res 73: 671-680.

54. DeYoung MB, Tom C, Dichek DA (2001) Plasminogen activator inhibitor type 1 increases neointima formation in balloon-injured rat carotid arteries. Circulation 104: 1972-1971.

55. Ploplis, VA, Cornelissen, I, Sandoval-Cooper, MJ, Weeks, L, Noria, FA, et al. (2001) Remodeling of the vessel wall after copper-induced injury is highly attenuated in mice with a total deficiency of plasminogen activator inhibitor-1. Am J Pathol 158: 107-17.

56. Prisco D, Fedi S, Antonucci E, Capanni M, Chiarugi L, et al. (2001) Postprocedural PAI-1 activity is a risk marker of subsequent clinical restenosis in patients both with and without stent implantation after elective balloon PTCA. Thromb Res 104: 181-186.

57. Samarakoon R, Dobberfuhl AD, Cooley C, Overstreet JM, Patel S, et al (2013) Induction of renal fibrotic genes by TGF- $\beta 1$ requires EGFR activation, p53 and reactive oxygen species. Cell Signal 25: 2198-2209.

58. Czekay RP, Wilkins-Port CE, Higgins SP, Freytag J, Overstreet JM, et al. (2011) PAI-1: An Integrator of Cell Signaling and Migration. Int J Cell Biol 2011: 562481.

59. Simone TM, Higgins CE, Czekay RP, Law BK, Higgins SP, et al. (2014) SERPINE1: A Molecular Switch in the Proliferation-Migration Dichotomy in Wound-"Activated" Keratinocytes. Adv Wound Care (New Rochelle) 3: 281-290.
60. Majesky MW, Lindner V, Twardzik DR, Schwartz SM, Reidy MA (1991) Production of transforming growth factor beta 1 during repair of arterial injury. J Clin Invest 88: 904-910.

61. Kanzaki T, Tamura K, Takahashi K, Saito Y, Akikusa B, et al. (1995) In vivo effect of TGF- beta 1 . Enhanced intimal thickening by administration of TGF- beta 1 in rabbit arteries injured with a balloon catheter. Arterioscler Thromb Vasc Biol 15: 1951-1957.

62. Schulick AH, Taylor AJ, Zuo W, Qiu CB, Dong G, et al. (1998) Overexpression of transforming growth factor betal in arterial endothelium causes hyperplasia, apoptosis, and cartilaginous metaplasia. Proc Natl Acad Sci U S A 95: 6983-6988.

63. Yutani C, Ishibashi-Ueda H, Suzuki T, Kojima A (1999) Histologic evidence of foreign body granulation tissue and de novo lesions in patients with coronary stent restenosis. Cardiology 92: 171-177.

64. Nikol S, Isner JM, Pickering JG, Kearney M, Leclerc G, et al. (1992) Expression of transforming growth factor-beta 1 is increased in human vascular restenosis lesions. J Clin Invest 90: 1582-1592.

65. Providence KM, Kutz SM, Staiano-Coico L, Higgins PJ (2000) PAI-1 gene expression is regionally induced in wounded epithelial cell monolayers and required for injury repair. J Cell Physiol 182: 269-280.

66. Providence KM, White LA, Tang J, Gonclaves J, Staiano-Coico L, et al. (2002) Epithelial monolayer wounding stimulates binding of USF-1 to an E-box motif in the plasminogen activator inhibitor type 1 gene. J Cell Sci 115: 3767-3777.

67. Deng G, Curriden SA, Hu G, Czekay RP, Loskutoff DJ (2001) Plasminogen activator inhibitor-1 regulates cell adhesion by binding to the somatomedin B domain of vitronectin. J Cell Physiol 189: 23-33.

68. Garg, N, Goyal, N, Strawn, TL, Wu, J, Mann, KM, et al. (2010) Plasminogen activator inhibitor-1 and vitronectin expression level and stoichiometry regulate vascular smooth muscle cell migration through physiological collagen matrices. J Thromb Haemost 8: 1847-54.

69. Degryse B, Neels JG, Czekay RP, Aertgeerts K, Kamikubo Y, et al. (2004) The low density lipoprotein receptor-related protein is a motogenic receptor for plasminogen activator inhibitor-1. J Biol Chem 279: 22595-22604.

70. Kamikubo, Y, Neels, JG, and Degryse, B (2009) Vitronectin inhibits plasminogen activator inhibitor-1-induced signalling and chemotaxis by blocking plasminogen activator inhibitor-1 binding to the low-density lipoprotein receptor-related protein. Int J Biochem Cell Biol 41: 578-85.

71. Akkawi S, Nassar T, Tarshis M, Cines DB, Higazi AA (2006) LRP and alphavbeta3 mediate tPA activation of smooth muscle cells. Am J Physiol Heart Circ Physiol 291: H1351-1359.

72. Czekay RP, Loskutoff DJ (2009) Plasminogen activator inhibitors regulate cell adhesion through a uPAR-dependent mechanism. J Cell Physiol 220: 655-663.

73. Pedroja BS, Kang LE, Imas AO, Carmeliet P, Bernstein AM (2009) Plasminogen activator inhibitor-1 regulates integrin alphavbeta3 expression and autocrine transforming growth factor beta signaling. J Biol Chem 284: 20708-20717.

74. Van De Craen B, Scroyen I, Vranckx C, Compernolle G, Lijnen HR, et al. (2012) Maximal PAI-1 inhibition in vivo requires neutralizing antibodies that recognize and inhibit glycosylated PAI-1. Thromb Res 129: e126-133.

75. Folkes A, Roe MB, Sohal S, Golec J, Faint R, et al. (2001) Synthesis and in vitro evaluation of a series of diketopiperazine inhibitors of plasminogen activator inhibitor-1. Bioorg Med Chem Lett 11: 2589-2592.

76. Charlton PA, Faint RW, Bent F, Bryans J, Chicarelli-Robinson I, et al. (1996) Evaluation of a low molecular weight modulator of human plasminogen activator inhibitor-1 activity. Thromb Haemost 75: 808-815.

77. Gils A, Stassen JM, Nar H, Kley JT, Wienen W, et al. (2002) Characterization and comparative evaluation of a novel PAI-1 inhibitor. Thromb Haemost 88: 137-143.

78. Bryans J, Charlton P, Chicarelli-Robinson I, Collins M, Faint R, et al. (1996) Inhibition of plasminogen activator inhibitor-1 activity by two 
Citation: $\quad$ Simone TM, Higgins SP, Higgins CE, Lennartz MR and Higgins PJ (2014) Chemical Antagonists of Plasminogen Activator Inhibitor-1: Mechanisms of Action and Therapeutic Potential in Vascular Disease. J Mol Genet Med 8: 125. doi:10.4172/1747-0862.1000125

Page 7 of 7

diketopiperazines, XR330 and XR334 produced by Streptomyces sp. J Antibiot (Tokyo) 49: 1014-1021.

79. Egelund, R, Einholm, AP, Pedersen, KE, Nielsen, RW, Christensen, A, et al. (2001) A regulatory hydrophobic area in the flexible joint region of plasminogen activator inhibitor-1, defined with fluorescent activityneutralizing ligands. Ligand-induced serpin polymerization. J Biol Chem 276: 13077-86.

80. Einholm AP, Pedersen KE, Wind T, Kulig P, Overgaard MT, et al. (2003) Biochemical mechanism of action of a diketopiperazineinactivator of plasminogen activator inhibitor-1. Biochem J 373: 723-732.

81. Friederich, $\mathrm{PW}$, Levi, $\mathrm{M}$, Biemond, BJ, Charlton, $\mathrm{P}$, Templeton, $\mathrm{D}$, et al. (1997) Novel low-molecular-weight inhibitor of PAI-1 (XR5118) promotes endogenous fibrinolysis and reduces postthrombolysis thrombus growth in rabbits. Circulation 96: 916-21.

82. Friederich PW, Levi M, Biemond BJ, Charlton P, Templeton D, et al. (1997) Novel low-molecular-weight inhibitor of PAI-1 (XR5118) promotes endogenous fibrinolysis and reduces postthrombolysis thrombus growth in rabbits. Circulation 96: 916-921.

83. Cale JM, Li SH, Warnock M, Su EJ, North PR, et al. (2010) Characterization of a novel class of polyphenolic inhibitors of plasminogen activator inhibitor-1. J Biol Chem 285: 7892-7902.

84. Suzuki J, Ogawa M, Muto S, Yamaguchi Y, Itai A, et al. (2008) The effects of pharmacological PAI-1 inhibition on thrombus formation and neointima formation after arterial injury. Expert OpinTher Targets 12: 783-794.

85. Izuhara $Y$, Takahashi S, Nangaku M, Takizawa S, Ishida H, et al. (2008) Inhibition of plasminogen activator inhibitor-1: its mechanism and effectiveness on coagulation and fibrosis. Arterioscler Thromb Vasc Biol 28: 672-677.

86. Elokdah H, Abou-Gharbia M, Hennan JK, McFarlane G, Mugford CP, et al. (2004) Tiplaxtinin, a novel, orally efficacious inhibitor of plasminogen activator inhibitor-1: design, synthesis, and preclinical characterization. J Med Chem 47: 3491-3494.

87. Hennan JK, Morgan GA, Swillo RE, Antrilli TM, Mugford C, et al. (2008) Effect of tiplaxtinin (PAI-039), an orally bioavailable PAI-1 antagonist, in a rat model of thrombosis. J Thromb Haemost 6: 1558-1564.

88. Lee SH, Eren M, Vaughan DE, Schleimer RP, Cho SH (2012) A plasminogen activator inhibitor-1 inhibitor reduces airway remodeling in a murine model of chronic asthma. Am J Respir Cell Mol Biol 46: 842-846.

89. Krause MP, Moradi J, Nissar AA, Riddell MC, Hawke TJ (2011) Inhibition of plasminogen activator inhibitor-1 restores skeletal muscle regeneration in untreated type 1 diabetic mice. Diabetes 60: 1964-1972.

90. Lijnen HR, Alessi MC, Frederix L, Collen D, Juhan-Vague I (2006) Tiplaxtinin impairs nutritionally induced obesity in mice. Thromb Haemost 96: 731-737.

91. Schalkwijk CG, Stehouwer CD (2006) PAI-1 inhibition in obesity and the metabolic syndrome: a promising therapeutic strategy. Thromb Haemost 96: 698-699.

92. Leik CE, Su EJ, Nambi P, Crandall DL, Lawrence DA (2006) Effect of pharmacologic plasminogen activator inhibitor-1 inhibition on cell motility and tumor angiogenesis. J Thromb Haemost 4: 2710-2715.

93. Crandall DL, Quinet EM, El Ayachi S, Hreha AL, Leik CE, et al. (2006) Modulation of adipose tissue development by pharmacological inhibition of PAI-1. Arterioscler Thromb Vasc Biol 26: 2209-2215.

94. Lijnen HR, Alessi MC, Van Hoef B, Collen D, Juhan-Vague I (2005) On the role of plasminogen activator inhibitor-1 in adipose tissue development and insulin resistance in mice. J ThrombHaemost 3: 1174-1179.

95. Weisberg, AD, Albornoz, F, Griffin, JP, Crandall, DL, Elokdah, H, et al. (2005) Pharmacological inhibition and genetic deficiency of plasminogen activator inhibitor-1 attenuates angiotensin II/salt-induced aortic remodeling. Arterioscler Thromb Vasc Biol 25: 365-71.

96. Pedersen KE, Einholm AP, Christensen A, Schack L, Wind T, et al. (2003) Plasminogen activator inhibitor-1 polymers, induced by inactivating amphipathic organochemical ligands. Biochem J 372: 747-755.

97. Björquist P, Ehnebom J, Inghardt T, Hansson L, Lindberg M, et al. (1998) Identification of the binding site for a low-molecular-weight inhibitor of plasminogen activator inhibitor type 1 by site-directed mutagenesis. Biochemistry 37: 1227-1234.

98. Brooks TD, Wang SW, Brünner N, Charlton PA (2004) XR5967, a novel modulator of plasminogen activator inhibitor-1 activity, suppresses tumor cell invasion and angiogenesis in vitro. Anticancer Drugs 15: $37-44$. 